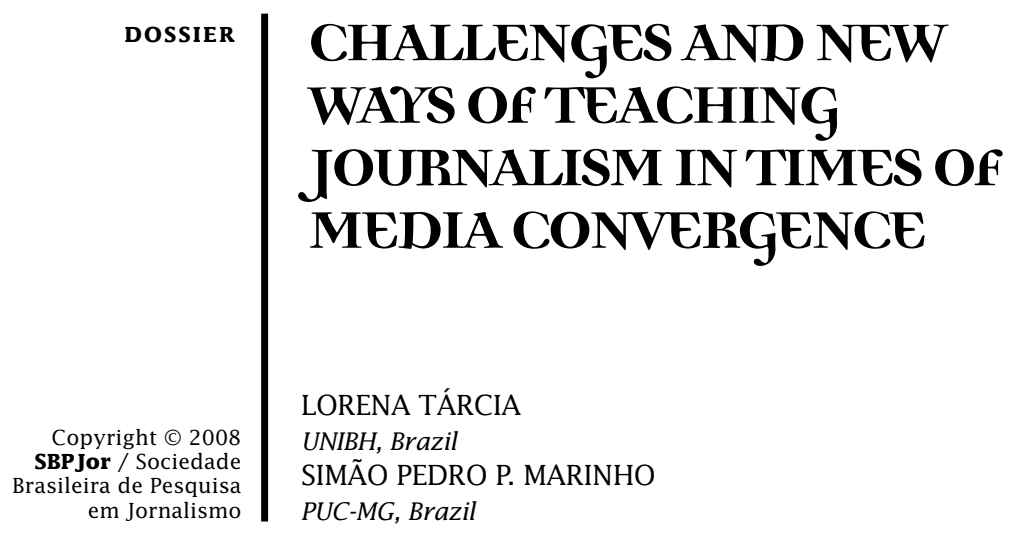

ABSTRACT This research investigated the training of journalists facing the challenges brought about by digital technology and the Internet. The objective was to develop strategies to assist students to become pro-active and so demand of the institution an educative process that satisfies the new professional requirements generated by media convergence. The results point to the need for journalism education to act together with the students in the search for alternatives capable of accompanying the changes, while also taking into consideration the users' interactive and participatory possibilities. Journalism degree courses are currently operating in a fragmented way, as consequence of the reality of the analogical media, and need to improve in order to train journalists capable of facing the new market realities, without losing the capacity for ethical reflection on their social responsibilities.

Key-Words: media convergence, communication, technology, journalism, education

\title{
INTRODUCTION
}

Since the invention of personal computers in the 70s, digital technology has expanded quickly, permeating society with new formats and possibilities of communication. Hypertext, multimedia, hypermedia have become part of the routine of the vast majority of professionals and require schools to change their ways of teaching and learning.

The newsrooms have embraced, to a greater or lesser degree, electronic or digital publishing, which has greatly changed the working environment and routines for production of all types of media.

For authors such as Lage (2001), the technological changes which occurred before the arrival of computers in newsrooms, such as layout, off-set printing, and even the emergence of radio and television "although extraordinary in terms of distribution and reception of news" 
- did not revolutionize the journalists' work.

Meanwhile, the computer has changed this reality, by creating a kind of Media Esperanto that technologically allowed the interaction of all kinds of news channels. The product of one media platform can now be used in another. The Internet potentially joins readers and producers of information around the world, demanding of journalists not only the mastery of new technologies, but also the ability to respond with great speed and accuracy to the interactivity made possible by individual demands.

The world communicates $24 / 7$. There no longer are deadlines or geographical barriers. The reader decides what, when and how to read, in addition to having a voice through low-cost digital publications, free of government interference.

Facing the changes in the media and in the press services, journalism schools have had to adjust to this new model. They have installed laboratories and created new subjects, reformulating curriculum structures and purchasing new equipment. Each one has been seeking, in its own way, to educate professionals able to satisfy the new demands of the labor market, according to the Ministry of Education (MEC), and of their audience.

Journalism schools used to believe that a successful career was guaranteed if the student knew a particular medium, and knew it well. Since the early stages of the course, students sought - and still seek - to define their professional preference: radio, TV, newspapers, magazines, press service. Now, however, the current way of organizing the media has shown that students should learn to communicate with a variety of audiences, using in addition to words, images, sounds and, in the near future, smell, taste and virtual reality.

Analog and digital live together on a daily basis in journalism. But the changes occur quickly. Professionals worldwide are discussing the New Journalism and New Journalist Training.

What would be the role of journalism schools in this context? Strong theoretical or deep technological knowledge? Respond to market demands or to the appeals of science? Theory or practice? These are complex issues and require a broad positioning of all the actors involved.

Media convergence and the training of the multimedia journalist is the subject of this paper. Utilizing the methodology proposed by Barbier (2004), augmented by the reflective teaching theory of Schön (2000), we performed interviews, followed by analysis and recording, with students in their first year of journalism. Our overall objective was to investigate, 
through action research, strategies for preparing students to be proactive and critical of their own culture of linear thinking, capable of demanding from the institution an educational process that satisfied the new professional requirements generated by media convergence.

\section{Media Convergence}

Nicholas Negroponte was the first to call attention to the phenomenon of media convergence, in speeches to raise funds for the construction of a headquarters for the Media Lab at the Massachusetts Institute of Technology (MIT).

People were amazed by Negroponte's "revelation" that all communication technologies were passing through a metamorphosis, which could only be understood when properly treated as a separate topic. Since then, the term "media convergence" has been used in various - and sometimes confusing - circumstances. For Quinn (2005, p.3), as beauty is in the eyes of those who see it, the definition of convergence depends on each person's perspective. Among its features is the fact that it varies from country to country, from culture to culture, from company to company.

Authors such as Grant (2007) have chosen to avoid its use. He argues that it is a phrase with generic sense, each one using it as it best suits him, based on experience and individual applications. The solution for that author would be to seek a replacement for each case as collaborative, cross-media, or multimedia platform.

In an attempt to refine the concept, Jenkins (2001) was categorical in stating that there will never be what the industry hailed as a single unit transmitter of news and entertainment, like the Dick Tracy watch. But we cannot ignore the fact that mobile gadgets are coming closer and closer to that.

There will never be one black box controlling all media. Rather, thanks to the proliferation of channels and the increasingly ubiquitous nature of computing and communications, we are entering an era where media will be everywhere, and we will use all kinds of media in relation to one another. We will develop new skills for managing information, new structures for transmitting information across channels, and new creative genres that exploit the potentials of those emerging information structures. (JENKINS, 2001, p.93)

It is necessary to understand that the confusion when using the term "media convergence" occurs because, when speaking about it, people 
refer to at least five processes in progress: [1] technological convergence, [2] economic convergence, [3] social or organic convergence, [4] cultural convergence and [5] global convergence.

For Negroponte (1995), technological convergence is the transformation of atoms in bits, the digitalization of the contents of all media. It occurs when words, images and sounds are converted into digital information, a phenomenon that expands the potential for integration between them and allows their flow between platforms.

Economic convergence is the horizontal integration in the entertainment industry. A single company, such as America Online, now controls interests in movies, television, books, games, web, in the real estate market and in several other economic sectors. The result has been the restructuring of cultural production around "synergy" and the exploitation of brands in the process of trans- or cross-media, as seen in movies like Superman, Harry Potter, Tomb Raider and Star Wars

Social or organic convergence is the strategy of multitasking consumers to navigate the environment of this new Information Age. Organic convergence, according to Jenkins (2001), happens when a university student watches football on high-resolution television, plays music on the iPod, types a text or writes an e-mail - everything at the same time, here and now.

The explosion of new forms of creativity and intersections of the various technologies of media, industries and consumers characterizes cultural convergence. Media convergence encourages a new culture of popular participation by allowing people to access the tools for production, storing, ownership and circulation of content. "Shrewd companies tap this culture to foster consumer loyalty and generate lowcost content", writes Jenkins (2001).

Media convergence also encourages trans-media storytelling, the development of content across multiple channels. The more fully consumers exploit the potential of organic convergence, the more content producers will use different ways to communicate various types and levels of information, choosing the media that most appropriately presents the content and meets the needs of their audience.

Global convergence is defined by Jenkins (2001) as being the cultural hybridism that results from the international circulation of media content. It is the case of music, news agencies and cinema. "The global circulation of Asian popular cinema profoundly shapes Hollywood entertainment. These new forms reflect the experience of being a citizen of the 'global 
village'. (Jenkins, 2001, p.93)

Whether in the form of production or distribution of content, the communications industry is changing and with it the consumers' habits. Studies made in the United States show the simultaneous use of various media and the increasing popularization in the consumption of content produced by individuals.

\section{The consequences of convergence in news media}

Palacios (2003) says that before talking about changes in the media, we must make some assumptions to avoid the temptation to consider the Internet and other digital media as opponents or to believe in the existence of a movement for surpassing the previous media formats. "Understanding the peculiarities of the various media does not mean putting them in opposition." (PALACIOS, 2003, pp.20, 21).

For Ramonet (2005), it was possible, until a few years ago, to distinguish between three virtually independent and autonomous areas in the world of communications: 1) information (press, radio information, news agencies, news from TV, chains of information, the universe of journalists); 2) advertising and 3) mass culture (soap operas, comics, literary publications for mass consumption, mass cinema, sports etc). One of the consequences of the digital revolution, according to the author, is the difficulty in maintaining clear distinctions between these worlds.

Pavlik and McIntosh (2005) consider that, even without consensus on the use of the term, convergence has transformed the nature of the media as a whole, with dramatic implications in four areas: 1) the structure of media businesses; 2 ) the relationship between the media business and its audiences; 3 ) working methods of communication for professionals and 4) the content of communication.

\section{Changes in media companies' structure}

The advent of new technologies in the field of journalism has changed not only the content but also the structure of media companies. On July 11, 2006, the publication Business Line31 brought into focus the headline: "It's all converging." The article expressed the fact that companies around the world were looking for lucrative ways to exploit the convergence of $\mathrm{TV}$, the Internet and mobile telephony, to confirm the public's access to all media and create content to meet individual audience needs.

The Innovations in Newspapers report, conducted annually by the 
World Association of Newspapers (WAN), in its 2001 edition evaluated the phenomenon of multimedia newsrooms, seen as an attempt by media companies to become Information Engines:

Newspapers throughout the world that have invested in other media are beginning to experience both the advantages and difficulties of a convergence whose catalyst is the Internet and whose immediate future will be the total integration of their news and commercial multimedia operations. (GINER, 2001, p.28)

The phenomenon of convergence became a subject for Innovations in Newspapers in 1999 and confirmed Negroponte's predictions made twenty years earlier. Two years after that first survey, in 2001, when answering a question concerning what stage they were at in terms of multimedia convergence, $73 \%$ of worldwide newspapers responded that "it was starting to happen". In 19\% of the newsrooms, convergence did not exist and only $5 \%$ of the newspapers considered themselves as models in this aspect.

The survey also noted that, curiously, unlike other phenomena in the communications industry, convergence was not restricted to the U.S. market. On the contrary, because of legislation which regulated and limited the existence of media conglomerates in the United States, most of the experiments were occurring in Asia, Europe, Australia, Africa and Latin America.

In the logic of media entrepreneurs represented in WAN, convergence has a clear meaning: cost reduction, productivity and expansion of markets. In the words of the Chief Executive Officer of the International Marketing Association of Newspapers, Earl Wilkinson:

Publish once, distribute many ways via print newspapers, city guides, web portals, the telephone, radio, and television. Broadband is the future, and newspapers must be a part of it. The multimedia newsroom is not 'news' but a common goal. (WILKINSON interviewed by GINER, 2001, p.28)

This aggressive strategy for business is seen as critical by the authors who believe in citizenship communication, socially responsible and dedicated to the preservation of local cultures. Moraes (1998) believes that, "the intimate relationship among telephony, TV, Internet and multimedia technologies disturbs the classical logic of subdivision." (MORAES, 1998, p.38). Today, companies integrate traditional communication consortia that manage privatized telephone companies and mobile operators; 
telecommunications companies are associated with the operators of cable television; satellite and software manufacturers are related to the electronic news agencies. This promotes a combination of interests and strategic powers of the so-called "info-telecommunications."

The media acts in both senses: to serve capitalist globalization and to interconnect the planet, via satellite, cable and optical fiber networks. The integrative feature is something intrinsic of the broadcast apparatus. I do not think there is another sphere of everyday life able to connect peoples, countries, societies, cultures and economies. (MORAES, 2005, p.189)

The global media is now in the hands of two dozen conglomerates, the so-called Gentlemen of the Air (ECHEVARRIA, 1999) or the Media Barons (FERRARI, 2004) with huge revenues. They convey two thirds of the information and cultural content available in the world. Time Warner, Vivendi Universal, Disney, Bertelsmann and Viacom are part of the ranking. Competition is restricted to a minimum number of companies. This degree of hyper-concentration, according to Moraes (2005), reproduces what happens in international trade, in which global corporations account for two thirds of all transactions.

[...] the info-telecommunication convergence establishes itself in the shadow of the growing oligopoly of media and services, even though the neo-liberal rhetoric still insists on the assumption of technological benefits. As this setting crystallizes, it is narrowing the field of maneuver for a stable and balanced development of information networks and increasing the structural gap, in the context of denationalization of the strategic areas of communication (MORAES, 2005, p.204).

To reach this point, communication companies went through three stages (GINER, 2001). The first stage, diversification, lasted until the 1980 s, when the proposed multimedia integration was a fiasco. At that time, media organizations invested in buying other companies, mainly to protect themselves from competition and to gain a greater share of the advertising market. The so-called synergy between these companies never happened in practice.

On the contrary, these media holdings barely managed to improve the group financial performance and the corporate centers were invariably seen as costly, bureaucratized and inefficient superstructures. (GINER, 2001, p.29) 
In newsrooms, editors refused to accept any foreign interference, even though the companies had the same owner. At the end of this stage, the culture and independence of each media prevailed.

For Moraes (2005), it was a link between the capitalist mode of production and Information Communication Technology (ICT), "a synergy that fosters the accumulation of financial capital in an economy of electronic interconnections" (MORAES, 2005, p.189). It was a time when, according to Dantas (2002), large corporations, through agents or directly, invested in the search for solutions that made the communication of information increasingly fast, efficient and cheap. The progress of microelectronics, the evolution of computers, artificial satellites, microwave transmission and optical fibers were the foundation of this business logic.

The second stage, called convergence ${ }^{1}$ by WAN in the early 1990s, is marked by the emergence of digital technologies, facilitating the unification of electronic media. From coexistence, companies started to cooperate.

Although the transition from the analog world to a digital one called for strategies that were still passive, these new companies - such as Japan's Nikkei Group and Brazil's Agência Estado, which were pioneers of this convergence - became 'post-newspaper' organizations (GINER, 2001, p.30).

It was a particular phase of investment and expansion for Brazilian companies. For example, the media group O Estado, which controls the newspapers $O$ Estado de S. Paulo and Jornal da Tarde, O Estado News Agency, the OESP printing company, the Eldorado AM and FM radios and Eldorado records, entered the mobile market. Its partners were the U.S. Bell South, Banco Safra and RBS, a Brazilian TV company.

It was also the period in which Bloomberg emerged as an unknown but visionary news agency, alongside the traditional Reuters, which has gone through a broad technological restructuration in a short period of time, providing news content in the world through digital multichannel.

According to the Veroni Suhl investment bank, the sectors of information and entertainment were the fastest-growing in the U.S. economy between 1994 and 2000, ahead of financial markets and services. During the 1990s, the industry system of communication adapted to the guidelines of the corporate-network, following the pattern of multi-sector investment by exploiting synergies and related branches in order to rationalize costs, reduce debt levels, combine know-how and promote scale economy. (MORAES, 2005) 
Pavlik and McIntosh (2005) point out that, although there are many public media companies, most of them are seeking financial gain. The concentration of media, a process that had already occurred in the analog world, expanded in the digital world.

Analog and digital media are rapidly being consolidated into the hands of a few very large, very powerful, and very rich owners [...]. These global media enterprises today are increasingly likely to be part of large, global media organizations publicly owned and accountable to shareholders whose main interest is the financial bottom line. (PAVLIK; MCINTOSH, 2005, p.72)

In the third stage, called by Giner (2001) integration, the Internet appears as a catalyst for a revolution in the media business and, in turn, requires even more aggressive editorial and marketing strategies. Organizations until then structured as "isolated stores of information" (GINER, 2001) came to believe that online journalism was a distinct phenomenon. Many entrepreneurs, especially in the United States, fell at that time into the trap of creating companies devoted only to entering this new market, with huge headquarters in futuristic buildings, hoping to launch shares on the stock exchange and take advantage of the speculative bubble that made the NASDAQ stock market index swell.

In other countries, unlike the American phenomenon, companies were less obsessed by the "new digital pipe dream of gold" (GINER, 2001, p.31). In Brazil, the newspapers O Globo, O Estado de S. Paulo and the $R B S$ Group were among those companies that were trying to transform themselves into Information Engines, and sought complete multimedia integration.

According to Moraes (1998), investment in telecommunications reached US\$ 10 billion in 1997. The Globo-Vicunha-Bradesco consortium took over the concessions for mobile service in the states of Minas Gerais, Bahia and Sergipe. In addition to the alliances in telecommunications, Globo Organizations began to use the 32 thousand kilometers of cables from networks built by Globocabo for providing Internet access and interactive services via broadband.

\section{Relationship between the media and their audiences}

Conceptions regarding the audiences are changing, according to Severin and Tankard Jr. (2001). Consumers of media are now seen as active users rather than passive recipients. Older theories of communication, such as the hypodermic theory, considered the users as passive beings, 
subject to the impositions of the media. In a classic study called "The stubborn audience", social psychologist Raymond Bauer (1964) showed that the public can be very active in the forefront of the mass media. Other studies have followed (Byrant; Street, 1988; Rubin, 1994) and confirmed the audiences' options of choice, to satisfy their own needs with regard to radio and TV programs or magazines and newspapers news.

Even if the audience has never been as passive as one has come to believe, we now witness a new phenomenon: interactivity and access of the public to the communication tools, from the perspective of a content producer. More than active, this new audience can be seen as participatory.

In April 2006, this change was portrayed by one of today's most respected magazines, The Economist. With the title Among the Audience, the research report stated: "The era of mass media is giving way to one of personal and participatory media. That will profoundly change both the media industry and society as a whole."(The Economist, 2006, p.3)

The Age of Participation goes beyond the so-called Era of the Internet and requires a new way of thinking about the worldwide network of computers, whose initial structure did not anticipate and does not involve the user on a large scale.

[...] even today's broadband infrastructure was built for the previous era, not the coming one. Almost everywhere, download speeds (from the Internet to the user) are many times faster than upload speeds (from user to network). This is because the corporate giants that built these pipes assumed that the Internet would simply be another distribution pipe for themselves or their partners in the media industry. Even today, they can barely conceive of a scenario in which users might put as much into the network as they take out. (THE ECONOMIST, 2006a, p.4)

This is exactly what is starting to happen. In November 2005, the Pew Internet \& American Life Project showed that $57 \%$ of American teenagers were creating content for the Internet, from text to photos, videos and audios. That does not mean that people "are writing their own newspapers," declared Yahoo engineer Jeremy Zawodny to The Economist (2006a). It may be that they are only voting on a restaurant or on a movie. But it also could mean production of excellent homemade videos.

This has profound implications for traditional business models in the media industry, which are based on aggregating large passive audiences and holding them captive during advertising interruptions. 
In the new-media era, audiences will occasionally be large, but often small, and usually tiny. Instead of a few large capital-rich media giants competing with one another for these audiences, it will be small firms and individuals competing or, more often, collaborating (THE ECONOMIST, 2006a, p.4)

For the founder of Technorati, David Sifry, "the lectures from one to many are turning into conversations between people otherwise known as 'audience'." (The Economist, 2006a, p.4) This new revolution is marked by neologisms. "Blog" became part of the Webster dictionary in 2004, the New Oxford American Dictionary adopted "podcast" in 2005. "Wikis", "Vlogs", "metaverse" and "folksonomies" may be next. They all relate to phenomena that occur in cyberspace with the user in the role of the leading man.

There is no doubt that changes are happening and they are visible and measurable. However, the meaning and its consequences are still far from being a consensus and are a cause for debate and speculation by those who advocate a break with the old paradigm and those who believe in continuity and a predominance of media with mass participation.

While in the view of a media businessman like Stephen Case (2002), chief executive of the giant AOL-Time Warner, digital convergence means greater power of choice for users, for Moraes (2005), the variety of contents for consumers will continue to be defined by the companies that command the media world.

Ramonet (2005) is another pessimist regarding any alternative to the dominant system of communication. According to him, "to communicate well, a series of techniques is necessary. Being in possession of the truth is not enough. Anybody can possess the truth and definitely not find any echo because they do not know how to communicate this truth." (Ramonet, 2005, p.251)

Moraes (2005), is also skeptical about any prospect for democratization of the news distribution channels. "Wherever you are intending to work in the media, the banner of a global player will be unfurled." (MORAES, 2005, p. 207). The guru of the American media, Barry Diller, is even more radical in his interview given to The Economist: "Self-publishing by someone of average talent is not very interesting. Talent is the new limited resource." (The Economist, 2006a, p.4)

Jerry Michalski, an adviser to large enterprises of communication in the United States, reacted with outrage to Diller's statement. For him, Diller is wrong about the limited amount of talented people in world. 
Look around and there's tons of great stuff from rank amateurs. [...]Not everything in the "blogosphere" is poetry, not every audio "podcast" is a symphony, not every video "vlog" would do well at Sundance, and not every entry on Wikipedia, the free and collaborative online encyclopedia, is $100 \%$ correct. But exactly the same could be said about newspapers, radio, television and the Encyclopaedia Britannica. (MICHALSKI, in an interview given to THE ECONOMIST, 2006a, p.4).

The novelty is that young people and the audience seem to be learning to identify on their own what is credible and what is not; what it is worthwhile and what does not deserve attention. Sometimes they do it with the help of an editor or reporter they trust; other times it is based on the filter of "collective intelligence" (LÉVY, 1995) and its cybercontacts.

Anderson (2006) believes that we are entering an era of cultural richness and abundant choices never before seen in history. He says the so-called peer production is one of the industry's strongest forces today. And Weinberger warns: "the era of participatory media must be understood not as a publishing phenomenon but a social phenomenon" (The Economist, 2006b, p.5)

In the mass media model, pre-Internet, people used to believe in one source of truth, which was represented by the media company that had the confidence of the reader / viewer. The current model has various sources and leaves the audience to take responsibility for their own conclusions drawn from the multiple truths available.

\section{How communication professionals work}

Wolton (1999) sees the modalities of media not as upward points in a gradual evolutionary scale, but as complementary. He calls attention to the large capacity of ICT for information provision and databases. However, the author makes it clear that the growth of the mass of information does not lead us to dispense with mediators.

Direct communication, without mediation, as a mere technical performance calls for dreams of individual freedom, but they are illusory. The network can provide access to a mass of information, but no one is a citizen of the world, wanting to know everything, about everything. The more information there is, the greater the need is for intermediaries - journalists, archivists, publishers, etc., - to filter, organize, prioritize. Nobody wants to assume the role of chief editor every morning. Equal access to information does not create equal use of information. Confusing one thing with another is techno-ideology. (WOLTON, 1999). 
Palacios (2003) considers as a "misplaced simplification" Lévy's (1999) estimates of a possible disappearance of journalism, or of the journalist as an intermediary, as a result of web development. For Palacios, with the growth of the mass of information available to citizens, the role played by professionals who exercise functions of filtering and sorting becomes even more crucial.

In our research, we assume that the journalist is not an endangered species, but one whose functions and routines are being altered drastically. Digital technology demands more of the reporter, who often has to learn several operating functions, working at the same time as producer, editor and executor. All those functions used to be distributed among various sectors. Lage (2001) argues that

the modern technique of journalistic writing survived the changes in working processes introduced at the beginning of the twentieth century. We used to think, at that time, about a segmentation of functions, such as an assembly line - the transfer to the newsroom of the Taylorism production model, based on the principle that he who takes on only a small task is able to execute it with maximum efficiency. It was supposed, for some time, that reporters should investigate, editors should write, copy-desks should confront and correct, the designer should assemble the pages and editors should control everything. (LAGE, 2001, p.20).

In the 1980s, companies began to change their tactics. As technologies became much more complex, the task of investigating, producing and disseminating news increased not only the skills required of a reporter, but also the speed of publication in the frenetic pace of writing instantaneously and $24 / 7$. We could say that with digitization, the journalist finally became a specialist, not in anything in particular, but in effective ways to perform journalism and make the newspaper quickly and widely available..

The multimedia process makes possible a production method in which each part of a media conglomerate can use products and equipment generated by other parts. It is increasingly common to find within the newsroom of the print media, radio and television studios that enable the production of material in various formats. The result is that journalists have less time to gather and write, producing more superficial stories.

Thus, a reporter can now write an article for the night edition, appear on the screen to talk about the same event on television 
and expand the information by suggesting links with other sites or events on the Internet. These practices keep costs at a low level by absorbing a portion of the time that journalists used to devote to their investigations, requiring them at the same time to have new professional skills (for example, a good-looking appearance on TV) and a writing style adaptable to all types of media. (KLINENBERG, 1999, p.7)

The pressure exists not only in relation to the time needed for the production of information for all the media, but also in relation to the adaptation of the language required for the completion of the characteristics of each channel.

With so many changes and requirements, Marcondes Filho (2000) also fears that journalists are going to spend a good part of their time in activities that involve graphics, icons and data processing, with less quality content.

The author also recalls that the preparation of each journalistic text remains essentially an individual task. The process of gathering, verification and publication of a page, or a newspaper, really has changed. Today, the journalists talk and consult less with their colleagues and the newsrooms have become less noisy.

Facing the screen, journalists are increasingly left to themselves. They act as super-bosses. In this sense, electronic individual work increases the so-called "exploitation of the value-added": journalists work more for the same amount of money, and are more prone to stress. (MARCONDES FILHO, 2000, p.51)

This concern makes sense. The research work Innovations in Newspapers (Giner, 2001) done by the World Association of Newspapers showed what the leaders of the sector considered as major obstacles to the convergence of media at that time. Three in every ten of those interviewed listed "lack of financial resources" (31\%), "the individualistic nature of journalists" (31\%) and "lack of modern multimedia publishing systems" (30\%) as serious obstacles to convergence.

For media entrepreneurs, the problem lies in the complex cultural relations that govern the coexistence of journalists and administrators, editors and reporters, editors and page designers, not to mention the difficulty of understanding between the various technical, commercial and editorial departments. According to newspaper owners, there still reigns in newsrooms the prejudice between users of PC and Mac, the editorial headlines choice between hard and soft news, information and entertainment, objectivity and analysis. Another difficulty is the 
coexistence of journalists from different media, and the old animosity among the professionals of radio, television, newspapers, magazines and news agencies. (GINER, 2001)

We must agree that the problems of coexistence and relationships have always existed and some of these issues need to be worked out together with future journalists, still in school. However, we should not seek a framework of the journalist in a model based exclusively on productivity and technical competence.

In our view, it is necessary to explain to future journalists, without prejudice, the logic of the information industry market, highlighting their professional and social responsibility to maintain the financial health of the enterprise for which they will work. Moreover, in convergence, the journalist must be on the battle line for acquisition and retention of the reader. In online journalism, for example, the business logic is inverted in relation to the products of analog communication. In the case of a printed magazine or newspaper, the consumer pays before he can have access to the content. The journalist does not have any responsibility to convince the reader to buy each page. On the other hand, on the Internet the user will only provide a financial return for the publisher if he remains on the site without falling into the temptation of jumping to the competitor' site, which is a mouse click away. Research shows that in the digital universe, the player does not have the same loyalty as he had to his newspaper or his magazine. Growth therefore is the responsibility of the journalist as an author, in keeping the reader's attention, making him stay on the page and come back many times.

Multimedia integration may be a strategy for the elimination of many conflicts; however, technology will never solve all the problems.

Much of the jealousy that media convergence has aroused in newsrooms is brought about precisely by those who present a comical and childish image of supposed 'multimedia journalists' armed with electronic gadgets that require them to have several arms, like ancient Oriental gods and goddesses, to be able to write words with one hand, tape audio with another, film video with a third and take photos with a fourth - all of those would be sent by wireless transmission instantaneously through antennas attached to their heads or from briefcases that would make Agent 007 look old-fashioned. . (GINER, 2001, p.33).

Saffo (1992), however, raises the risk of "techno-myopia", a phenomenon that leads to underestimating the potential for short-term impact of new technologies and overestimating their implications for the 
long term. "First, we over-shoot and then under-shoot." (SAFFO, 1997, p.1)

We cannot be techno-myopes or techno-maniacs. The answer is in the balance. Tyner, former editor of the Chicago Tribune and current vice president of the print division of the Tribune Company, is one of the pioneers in the work of editorial integration. He says that the key in this process is to maintain the "journalistic soul", instead of being obsessed with the "galaxy of new technological tools" (GINER, 2001, p.33). The newsroom has to continue being the main pillar of any change, the journalist declares.

\section{News content}

Thompson (1988), Wolton (1999), Pavlik and Mclntosh (2005) and Saffo (2005) draw a distinction between a logic of supply, characteristic of traditional media (radio, TV, printed newspapers and magazines), which work by issuing the message (the so-called model One $\leftrightarrow$ All), and a logic of demand, characteristic of ICT, which works by providing access (the so-called model All $\leftrightarrow$ All). Digitization transforms how and when companies provide notice of their contents. The updating of news happens 24 hours a day for a worldwide audience, changing the logical relationship of producer / receiver.

The process of convergence is leading to a complete review of the term "mass". Although media companies continue to produce content for large audiences, often members of these audiences will tailor messages for particular users who will become much more active in their involvement with mediated communication than they have been until now.

Associated with interactivity and multimedia use of language, the speed of circulation inaugurates the era [...] called "turbonews." Webjournalism offers content that can be updated constantly. In that sense, this is the first time in the history of communication that the printed text reaches a speed in the reporting of information and events that before was possible only via TV or radio. (CORREIA, 2005).

Basically, convergence is changing the types of media to which the public has grown accustomed and this undoubtedly represents a shift even greater than that caused by television in the last century (SAFFO, 1992). In the pre-convergence world, the process of communication was a system of messages conveyed by words, pictures and sounds. The world of media convergence still has traces of these elements. However, new paradigms that are only possible with digital media network are 
added. "Stories told in a digital, online medium can make connections with other types of content much more easily than in any other medium." (Pavlik and McIntosh, 2005, p.68).

Miyagawa (2001) calls these new possibilities Personal Media and highlights the possibility of intervention by the spectator in the content, as opposed to the limitations of mass media. "In mass media, the content is sacrosanct and legally protected from appropriation by others". (Miyagawa, 2001)

In an interview given to The Economist, in 2006, Semel, director of Yahoo!, recalled that in the past, someone decided that the newspaper would go on the air at a given time and there was plenty to do, not subject to the decision of programmers. "Now the user is the programmer." (SEMEL, 2006, p.13) The logic in the programming of a portal like Yahoo! is based on the user's freedom of choice, which means he can either remain with the content of the website, or skulk to a competitor's site. This relationship of trust, Semel believes, will make the user return, building a deeper relationship (deeper involvement).

As people spend more time on Yahoo's pages, news, blogs, e-mail, chat groups, photo and music sites and so on - whether as their final destination or as stops on a journey - Yahoo! can put more and better advertising in front of theme. (SEMEL, in an interview given to THE ECONOMIST, 2006b, p.13).

For Pavlik and McIntosh (2005), the content in digital media is more fluid, dynamic, fast and comprehensive, "which enables better representations of events and processes in real life" (Pavlik and McIntosh, 2005, p.68). Moreover, the user increasingly receives information on demand. The technology even allows the user to choose, in the case of digital TV, through which camera the viewer wants to watch the football game or re-transfer, build his own replay.

This is not to say that everyone will want to - or should be a television director whenever they watch television. Sometimes passively consuming media is all a person wants. But that is not to say that simply being able to be a more active participant in the kind of content one is watching won' $t$ alter how mass communication content and media in general are perceived. (PAVLIK; McINTOSH, 2005, p.68)

Another striking difference between the content of mass media and that which is made available online is the fact that the Internet does not depend on big hits and successes to ensure instant audience, Semen tells 


\section{The Economist:}

Many small audiences are as good for advertisers as a few large ones, and indeed may be better. This has huge implications for content, turning it into one long continuum - from professional to amateur, from blockbuster to subculture niche. . (THE ECONOMIST, 2006b, p.8, our translation).

Besides the change in the logic of production, distribution and reception of content, there is the aspect of time and speed with the possibility of information in "real time", the name given to news instantly posted on the network.

We live in a crazy time in which the information is so rapid that it requires instant explanation and so superficial that any explanation serves. (VERÍSSIMO, 1999)

These words of Verissimo portray a reality in the era of convergent journalism, where the speed often tramples on the work of a careful news investigation. The logic of real time affects the practice of journalism as a whole, radicalizing the race against the clock that has always marked the profession. Moreover, the requirements of the financial market, and of those whom it serves, will set the clock for news in general. (Moretzsohn, 2002, p.130).

Speed and pasteurization are what the ombudsman of the newspaper Folha de S. Paulo, Renata lo Prete (2000), defined as "all the same dot com" when reporting the search for information about a sporting event.

This phenomenon should be carefully observed and worked on in journalism schools, where we can already observe the reflection of pasteurization, from the resistance of many students to the theoretical subjects and their overvaluation of the practical ones. With the students looking forward to feeling ready as soon as possible to deal with the day-to-day occupation, readings and reflections are discarded and end up compromising the process of learning in the widest sense.

\section{Action-research}

With all these issues in mind, in 2006 we started a research work for our Master Degree in Education called Media Convergence Project at the School of Journalism where we teach. The school is part of the Communication Faculty at the University Center of Belo Horizonte, State of Minas Gerais, in Brazil. The university has 39 under-graduate and 
12 post-graduate courses. The journalism degree is a four-year course and now has 800 students with 200 graduates per year. It is offered at either morning or evening sessions in accordance with the students' occupations.

In Brazil we have media convergence experiences happening in the larger media companies. Right now, in Minas Gerais, our biggest media conglomerate (TV station, radio, newspaper, Internet access provider) is introducing the figure of Convergent Reporter. The schools, however, still teach in a fragmented way.

In 2001, our university added two subjects to cover the digital media: Multimedia Fundamentals offered in the second semester and Online Journalism in the seventh semester, two years later. Between those two subjects, the students work predominantly on analogic-based technology.

We do not have what Don Tapscott calls the Digital Generation; it is more what we prefer to call a Screen Generation. In Brazil, students' main digital experience is connection through mobile phones. Computers are used for entertainment, e-mail and basic school research and work.

Taking into consideration reality and the data collected before the research, we decided to work with the students by trying to turn them into "Agents of Convergence". We thought that if they were aware of the convergence process and the changes occurring in journalism, they could help to change the ways in which things were happening at school.

The action research took place over a six-month period, but the project is still continuing. We work with second semester students and two other professors are involved; one teaching Portuguese and the other, Anthropology.

The project is divided into three parts:

1. The first part is based on a "multimedia blogosphere" concept, using Multiply ${ }^{2}$ as the platform. Students work in pairs and the goals are:

1. To understand the consequences of digitalization

2. To understand the technological evolution of each medium

3. To learn the basic tools for convergence

At the main page ${ }^{3}$ of the project, we use resources like hypertext, audio, video and photos to talk and interact with students about convergence and journalism. We also form a community linking morning 
session students to those attending the evening sessions to promote discussion and dialogue on the project.

We use a meta-linguistic process to study each medium. To learn about printed media evolution, we use text and hypertext. Students carry out research and interview teachers and journalists in order to write an article about the issue of the technological evolution in printed media. It is published on the blog ${ }^{4}$, using the Eyetrack Research as reference for the format.

To study the changes in photography, we make a timeline ${ }^{5}$, using Photoshop for editing of the slides. The students visit newspapers and talk to photographers about the changes occurring in photojournalism .

To talk about the technological evolution in the radio world, we make podcasts. The students visit local radio stations and use Audacity for edition. An example of a podcast, unfortunately in Portuguese, can be accessed at http://vanila32.multiply.com

Following the same logic, we make videocasts ${ }^{6}$ to talk about the technological evolution in the television world. We use Audacity to record audios and Windows Movie Maker for videos

2. The second part of the project involves the application of the tools that the students have learned in order to tell a story using multimedia. Again we use the Multiply ${ }^{7}$ platform.

The story is related to the research they do for Anthropology, specifically about urban tribes. The students are divided into groups of five and their goals are:

- $\quad$ to tell a story using audio, video, hypertext, photos;

- to be able to decide which types of media to use;

- to use the available interaction tools

They use text and hypertext to publish weekly updates ${ }^{8}$ about the experience and the project research and findings. They also publish a collection of links ${ }^{9}$ about the subjects and choose which media to use to better express parts of the story, e.g. music, recorded interviews, and podcasts.

During this process, students also use videocasts ${ }^{10}$, video interviews, slide shows ${ }^{11}$ and photos in different ways to tell the stories about the research and the various urban groups they are studying. 


\section{The third part of the project is about cross-media storytelling}

They students are divided into groups of 8 . Each semester we change the subject. Topics so far have included the World Soccer Cup ${ }^{12}$, media and life ${ }^{13}$, the city of Belo Horizonte and so on. The objectives are to be able to adapt the story for each media.

The students are asked to make a virtual representation of a control panel of all the media they are using according to the subject they are going to cover. It is interesting to note that the representation of the panels is not usually made on computers. The students draw parts by hand or cut out the figures from magazines and paste the various panels onto a sheet of paper using glue. A kind of analogical "cut and paste"

After that, having basically covered the theory, they do the research and write the stories according to the media. Based on that research we print a four-page newspaper ${ }^{14}$.

They then record a thirty-minute radio show ${ }^{15}$ using a professional radio studio and they also make a TV program ${ }^{16}$ about the subject, but we do not allow them to use recorded interviews. Using their own words, they themselves have to tell the story in front of the cameras. This is where the Portuguese Language professor becomes involved in assisting them to adapt their text to the media.

Finally they make a website ${ }^{17}$ which includes all the other media together with interaction facilities. The website also shows details of how the project is made, again using different media to tell this "behind the camera" story.

The results so far are as follows:

- We can say we have been quite successful in turning them into pro-active students. Indeed it has been one of the most exciting projects they have undertaken in their course, and they enjoy it very much.

- They have started to use multimedia in other subjects and semesters.

- However, the conclusion is that to establish a culture of multimedia convergence in the course, the project by itself is not enough.

- We need to involve the whole school in a program like that, including the other teachers and subjects.

The next step, therefore, involves a more extensive program, working on a more flexible curriculum and integrating the whole School of Journalism. 


\section{| NOTES}

1 Despite the fact that the WAN report, written by Giner (2001), considers convergence as a stage which has passed, we shall refer to the definitions of Jenkins (2001), who treats it as an ongoing process.

2 http://multiply.com/

3 http://fundamentos07.multiply.com/

4 http://vanila32.multiply.com/journal/item/3

5 http://vaarruda.multiply.com/photos/album/2

6 http://vanila32.multiply.com/video/item/8/De_Fio_a_Pavio_na_TV

7 http://aiafundamentos.multiply.com/

8 http://mercadocentral.multiply.com/journal

9 http://mercadocentral.multiply.com/links

10 http://mercadocentral.multiply.com/video/item/5

11 http://mercadocentral.multiply.com/photos

12 http://br.geocities.com/muraldeberlim/

13 http://www.convergencia.jor.br/midiasgerais/home.htm

14 http://www.convergencia.jor.br/midiasgerais/press.htm

15 http://www.convergencia.jor.br/midiasgerais/radio.htm

16 http://www.convergencia.jor.br/midiasgerais/tv.htm

17 http://www.convergencia.jor.br/midiasgerais/home.htm

\section{BIBLIOGRAPHY}


ANDERSON, Cris. The long Tail: Why the Future of Business Is Selling Less of More. New York, Hyperion, 2006

BARBIER, René. A pesquisa-ação. Trad. Lucie Didio. Brasília: Liber Livro Editora, 2004

CORREIA, João Carlos. O jornalismo e o sistema político: audiências e manipulação. Portugal: Labcom, 2005. Available at http://www. labcom.ubi.pt/agoranet/06/correia_jornalismosistemapolitico.pdf

ECHEVERRÍA, Javier. Los señores del aire: Telépolis y el tercer entorno. Barcelona: Destino, 1999.

GINER, Juan Antonio. Innovations in Newspapers 2001. France: World Association of Newspapers, 2001

GRANT, A. (2007). Lessons from the Keyboard. In: Convergence Newsletter from Newsplex at the University of South Carolina, Vol. V No. 2. Aug. Available at: <http://www.jour.sc.edu/news/convergence/v5no2. html >. Accessed on October 20, 2007.

JENKINS, H. (2001). Convergence? I diverge. Technology Review, Massachussets, June, p.93.

KLINEMBERG, Eric. Journalistes à tout faire de La presse américaine. In: Le Monde Diplomatique, Aug. 1999, p.7-9. Accessed on March 5,. 2006.

LAGE, Nilson. A reportagem: teoria e técnica de entrevistas e pesquisa jornalística. Editora Record, Rio de Janeiro, 2001.

LÉVY, Pierre. A inteligencia coletiva: por uma antropologia do ciberespaço / . 2.ed. São Paulo: Loyola 1999.

LO PRETE, Renata. Tudo igual ponto com. In: Folha de S.Paulo, April 16, 2000

MARCONDES FILHO, C. Comunicação e jornalismo: a saga dos cães perdidos. São Paulo: Hacker Editores, 2000. 
MIYAGA, Shigeru. Mídia pessoal. Massachussets Institute of Technology, 2001.

Class in vídeo available at:

h t t p : / / w w w. un ivers i a. com.br/mit / c u r s o. jsp?menucurso $=60 \&$ codcurso $=25>$ Accessed on Sept. 28,. 2008

MORAES, Denis de. Planeta Mídia: tendências da comunicação na era global. Campo Grande, Letra Livre, 1998

MORETZSOHN, Sylvia. Jornalismo em "tempo real": o fetiche da velocidade. Rio de Janeiro: Revan, 2002.

NEGROPONTE, Nicholas. A vida digital. São Paulo, Companhia das Letras, 1995.

PALACIOS, Marcos. Ruptura, continuidade e potencialização nojornalismo on-line: o lugar da memória. In: Digital. MACHADO, Elias e PALÀCIOS, Marcos. Modelos de Jornalismo. Salvador: Edições GJOL e Ed. Calandra, 2003

PAVLIK, J.; MCINTOSH, S. (2005). Convergence and its consequences. In: BUCY, Erik P. B. Living in the Information Age: a new media reader. 2nd.ed. USA: Thomson Learning. p.67-73.

QUINN, S. (2005). Convergent Journalism: The Fundamentals of Multimedia Reporting. United States: Peter Lang Publishing.

RAMONET, Ignácio. O poder midiático. In: MORAES, Denis (org). Por uma outra comunicação: mídia, mundialização cultural e poder. Rio de Janeiro, Record, 2005

SAFFO, Paul. The 30-year rule. Design World, 24 (1992). Available at <http://www.uiowa.edu/ c019166/166s5online2/saffol.html> Accessed on August 27,. 2006.

SCHÖN, Donald A.. Educando o profissional reflexivo: um novo design para o ensino e a aprendizagem . Porto Alegre: Artmed Editora Ltda., 2000

SEVERIN, Werner J; Tankard Jr., James W. Uses of Mass Media. In: BUCY, 
Erik P. B. Living in the Information Age: a new media reader. 2nd ed. USA, Thomson Learning, 2005, pp. 59-63.

THE ECONOMIST. (2006a). Among the Audience: the survey of new media. London, April.

THE ECONOMIST.. (2006b). Web 2.0: The enzyme that won. Available at: <http://www.economist.com/science/displayStory.cfm?story_ $\mathrm{id}=6911109>$. Accessed on September 7, 2006.

THOMPSON, John B.. A mídia e a modernidade: uma teoria social da mídia. 2. ed. Petrópolis: Vozes, 1998. 261 p.

VERÍSSIMO, Luís Fernando. Rio de Janeiro: O Globo, April 1,. 1999, p.7.

WOLTON, Dominique. Internet, e depois? Porto Alegre, RS: Ed. Sulinas, 2003

Lorena Tárcia is a Journalist, Master of Education from the Catholic University of Minas Gerais and professor of the Journalism Course at the University Center of Belo Horizonte (UNIBH). Member of the Research Group on Education and Digital Technologies, CNPQ. E-mail: lorenatarcia@gmail.com

Simão Pedro P. Marinho is a professor and Deputy Coordinator in the Master's Program of Education at the Pontifical Catholic University of Minas Gerais. PHD in Education (Pontifical Catholic University of São Paulo). Leader of the Research Group on Education and Digital Technologies, CNPQ.E-mail: sppm@uol.com.br 